\title{
E-GOVERNMENT IN SERVICE DELIVERY AND CITIZEN'S SATISFACTION: A CASE STUDY ON PUBLIC SECTORS IN BANGLADESH
}

\author{
M. Rezaul Karim
}

Faculty Member

Bangladesh Public Administration Training Centre, Savar, Dhaka-1343, BANGLADESH\& Ph.D. Candidate in Development Administration, National Institute of Development Administration, Bangkok, Thailand.

\begin{abstract}
:
In the traditional form of public administration, service delivery is encircled with paper based long procedures that makes the citizen dissatisfied with the services because of several problems such as delay in the service, corruption and offices are centrally located. In order to provide better services to the citizen Bangladesh government has taken the initiatives to make services available through online. In this regard, government has established national web portal, combining and making all government official websites interactive. General people now can submit their applications through online to get necessary public services. Government breaks the rigid boundary between government offices and citizen and reaches to the people so that they can get public services from their houses. This paradigm shift from traditional public administration to e-governance brings changes in service delivery. It minimizes time, costs, corruption and omits middle man culture and ultimately makes people happy. This paper utilizes qualitative approach to examine the process, benefits of recent innovations initiated by the democratic government and analyze the people's perceptions. It is found that utilizing the e-government infrastructure Bangladesh government has reached to the people and provided services at their doorsteps by establishing the national web portal through which citizen can access their useful services. Regarding the public services related to health service, education service, bill payment of necessary services, income tax payment, trade licence, land records, agricultural issues, law and order service are now easily enjoyed from the house through internet. However, the faster speed of customer demand in getting all services cannot be addressed with the limited IT infrastructure, unskilled manpower, limited electricity supply which should be solved as quickly as possible by emphasizing and initiating new programs. Findings show that government should think the intended and unintended consequences of materializing some initiatives and take necessary steps before intensifying the problem and making people unhappy with the services that have already been provided.
\end{abstract}

\section{KEYWORDS:}

Public Administration, Public Service, E-government, Web Portal, Bangladesh

\section{INTRODUCTION}

The philosophy of new public services centers the values and service of business to be provided to the citizen that goes beyond the old public administration and one step ahead of new public administration [1]. In the field of public administration the twenty-first century is viewed as the citizen-centric time for providing better services in numerous ways where public service will change the dimension. The Egalitarian government has the endeavour to bring good to people, society and country as a whole for which every government acclimates public policies, undertakes programmes and welfare projects with an objective to satisfy citizen by providing 
services to them. The more customer-oriented programs bring more benefits and satisfaction. Moving from the old paradigm of public services confined in official settings to virtual offices, services are made available for the citizen at their convenient points by setting and changing mechanisms such as virtual office, decentralization, public-private initiatives. The technological development has made radical change in this regard along with other public administration concepts [2].

With the constant change in everywhere, the increasing demand of citizen, various involvements in life, citizen can hardly manage time to seek public services; rather government organizations have taken different initiatives to provide services to the people (http://www.bangladesh.gov.bd/). Service sector of both public and private has been trying to make people's life easier.

In line with the changes happened in the public service globally Bangladesh government has taken initiatives for providing better services to the citizen. The government has emphasized on establishing e-government mechanism in government sector sticking to the election manifest. Moreover, weaknesses of traditional public service delivery that is time-consuming, long procedure, lack of transparency hinder providing services to the citizen in a timely and quality manner [3]. E-governance is treated as an effective mechanism to meet the citizen demand since it has the capacity to create new methods and avenues for participation in government, minimizing gaps, building together citizens through internet, hassle-free businesses, providing faster and better communication, increasing competition [4]. Due to e-governance, citizens transact themselves, it reduces cost, minimizes third-party contact. Moreover, they can get government services at their doorsteps in an efficient and cost-effective manner (http://www.bangladesh.gov.bd/). The ultimate outcome of this innovation is people's satisfaction that leads to happiness. There are many reasons to undertake these initiatives of which benefits are to be evaluated. This paper has an attempt to find out the significance of undertaking government projects for the citizens as well as examine people's response.

\section{METHODOLOGY}

This paper employs the qualitative approach on the basis of data collected from the secondary sources of data. Various reports, government publications, published articles in the print media and journal are the major sources. This paper analyses various issues on various public services provided by the government. It covers education sectors, land related service, agriculture issues, law and order, health service etc. It mainly follows the document analysis based on available secondary resources iterative to e-government, public services, service strategies and tools, relevant laws and expectations of citizen [5]. Online resources are the major sources of data collection techniques.

\section{RECENT INNOVATIONS IN THE PUBLIC SERVICE IN BANGLADESH}

Before 2009 the Sheikh Hasina government comes to power, the government had been maintaining the traditional way to providing service to citizen. People used to the government offices for their problems to be solved. The service area covers related to law and order, land litigation, judiciary, education information, postal communication, government allocation for the local government bodies and so on. For each and every issue people had to travel to district or capital city even for just getting primary information. The Sheikh Hasina government has taken the initiative to minimize the people's hazards so that they can available necessary information and services from their house or nearest places. Keeping this in mind government planned and implemented a program titled 'Access to Information (A2I)' to bring the services to their 
doorsteps. This program was initiated and implemented with the direct financial help of UNDP (http://www.bangladesh.gov.bd/).

It is a revolution in information technology (IT) area in Bangladesh that whole Bangladesh is connected through internet with all sorts information available online. All 7 divisions, 64 districts, 487 sub-districts, 4550 unions and 55 Ministries \& divisions, 251 attached departments are inter and intra connected linking through the national web-portal of Bangladesh (http://www.bangladesh.gov.bd/). National web portal is the portal that is specially designed binding all necessary together in a uniform way so citizen can easily get any information about government services from one point. All government offices like ministries, departments and other subordinate offices have websites with available necessary information. Some websites are interactive for providing services to the citizens. People can collect any necessary information from the website, can apply for intended services and can get reply though email as well which eservices were beyond imagination few years back. In spite of limitations and obstacles of traditional bureaucracy and traditional system of public administration, government has brought tremendous success in this sector. However, centralized policy of the government i.e. maintaining technical and financial support from the Prime Minister's Office (PMO) has materialized this project. National web-portal frequently renamed as National e-portal has made life easy for citizen by providing all necessary information and services. Few years back it was impossible to get information available in the internet. The Right to Information (RTI) Act 2009 has played a vital role in developing those resourceful websites [6].

\subsection{THE POTENTIALS REASONS TO UNDERTAKE THESE INITIATIVES:}

The limitations of traditional public administration have forced to undertake recent initiatives for providing time bound, quick and pro-people services. A public service is must be effective for its customer in terms of values, outputs where the satisfaction is a main concern that depends on a number of dimensions, such as service quality, speed, timing, availability of resources, human interaction and relation etc. Academics and researchers found that services are associated with many things combining direct and indirect costs for delay and uncertainty, lack of transparency, corruption, involvement of third party, mistrust or ill-treatment by the officials, productivity of the citizen and business procedures, travelling cost for staying around office to get the jobs done [6,7]. These are issue of traditional public administration, particularly centralized bureaucratic system where everything based in the capital and citizens have to suffer a lot. The paper based bureaucratic procedures have also created multi-dimensional obstacles in getting public services. Because these negative aspects of traditional public administration new paradigm of public administration emerged as the e-governance paradigm changing in many areas (table-1):

Table-1: Paradigm shift of Public Administration and Change of Patterns in Service Delivery

\begin{tabular}{|c|c|c|}
\hline Aspects & Bureaucratic Paradigm & E-Government Paradigm \\
\hline Orientation & Production cost-efficiency & $\begin{array}{l}\text { User satisfaction and control, } \\
\text { flexibility }\end{array}$ \\
\hline Process Organization & $\begin{array}{l}\text { Functional rationality, } \\
\text { departmentalization, vertical } \\
\text { hierarchy of control }\end{array}$ & $\begin{array}{l}\text { Horizontal hierarchy, network } \\
\text { organization, information } \\
\text { sharing }\end{array}$ \\
\hline Management Principle & $\begin{array}{l}\text { Management by rule and } \\
\text { mandate }\end{array}$ & $\begin{array}{l}\text { Flexible management, } \\
\text { interdepartmental team work } \\
\text { with central coordination }\end{array}$ \\
\hline Leadership Style & Command and control & $\begin{array}{l}\text { Facilitation and coordination, } \\
\text { innovative entrepreneurship }\end{array}$ \\
\hline
\end{tabular}




\begin{tabular}{lll}
\hline Internal Communication & Top down, Hierarchical & $\begin{array}{l}\text { Multidirectional network with } \\
\text { central coordination, direct } \\
\text { communication }\end{array}$ \\
External Communication & $\begin{array}{l}\text { Centralized, formal, limited } \\
\text { channels }\end{array}$ & $\begin{array}{l}\text { Formal and informal direct } \\
\text { and fast feedback, multiple } \\
\text { channels }\end{array}$ \\
Mode of Service Delivery & $\begin{array}{l}\text { Documentary mode and } \\
\text { interpersonal interaction } \\
\text { Principles of Service Delivery } \\
\text { Standardization, impartiality, exchange, non face } \\
\text { equity }\end{array}$ & $\begin{array}{l}\text { User interaction } \\
\text { to facen customization, }\end{array}$ \\
\hline
\end{tabular}

Source [9]

\subsection{SERVICES PROVIDED TO THE CITIZENS}

The PMO of Bangladesh is in the central position to initiate, maintain and sustain the e-service mechanism through national web portal (http://www.bangladesh.gov.bd/). A good number of functions of public administration are now administered through e-service. This web portal provides all necessary information about local government, health, education, social services, law and order, judiciary, local and national development, contact persons for specific services, related forms and applications, related web addresses, fees etc (http://www.bangladesh.gov.bd/). The national web-portal provides two types of functions, one is accumulation of information and hoisting all necessary information regarding public services, and second one is providing services through interactive websites.

\subsection{LAND RELATED ISSUES:}

As the agriculture based economy, people are mostly dependent on land in Bangladesh. People used to go to land office for calculating tax, paying tax, mutation, getting records etc. Since paper based documents were then available or man-made calculation, there was a possibility of miscalculation, cheating, harassment in terms of paying taxes (http://www.bangladesh.gov.bd/). Now district offices came forward to calculate land tax through their interactive websites. It minimizes costs and time of the service recipients. Some projects have been aligned to extend the services for the citizens. It is one of the pivotal useful services provided by the public offices at the district level and top most priority service included in the first pilot project.

\subsection{EDUCATION SERVICES:}

It was beyond imagination to get any kind of academic results sitting in their houses. All academic institutions, government education departments are now providing any services through mobile, internet by sending short message or email or putting the academic numbers which could take much time to get the required outputs. This system covers examination results, admission results, application for admission, knowing necessary documents, fees and other services (http://www.bangladesh.gov.bd/). Some universities combined their admission test so that students can easily sit for examination from their suitable places and can avail the services with the limited cost. Students can collect their provisional certificates from any point of internet providers including union information service center at the rural level. As government encourages private organizations to come forward, online schooling started. It is innovative project initiated by the Grameen ${ }^{1}$ Phone that online school creates a classroom for deprived children living in

\footnotetext{
${ }^{1}$ The Biggest Bangladeshi Mobile Operator Company which is currently a partner organization of Norwegian Telenor company.
} 
remote Bangladesh. A remote classroom is connected online with a classroom in Dhaka, where the teacher conducts the session using video conferencing technology, along with the support of assigned staff at remote classroom. In this classroom leaning students and teachers can interact (http://www.telenor.com/sustainability/initiatives-worldwide/online-school-launched-inbangladesh/).

\subsection{HEALTH SERVICES INFORMATION:}

Besides providing necessary information regarding health facility for citizens, it has become an important service to book doctors through online and meets according to the citizen's time. The citizen charter including necessary to be provided for the primary and secondary health care is exhibited either in front of any health complex across the country and hoisted in the websites of all health related decentralized and centralized government websites (http://www.bangladesh.gov.bd/). This information is for both internal and external customers.

Internal customers includes all employees of health service who can utilize for their service records, career development, training programs both in country and abroad. External customer entails all citizens who can utilize this information for their purpose. Medical education information is also found and disseminated through health related websites.

\subsection{ORDINANCE, ACTS, VARIOUS FORMS ARE AVAILABLE IN THE WEBSITES:}

The only way to get any government publications was the collection of hard copies government offices particularly in the capital city or some district level offices. The communication cost was much to get the simple services. It would create third party involvement, specially the corrupt officials or touts who used to charge extra money for any documents. Government has made now available in the websites of concerned ministries or departments. Regulatory Reform Commission has compiled almost all ordinances and made free for all. Unavailability of necessary documents would create spiral problems leading to delay or inaccess to the services.

\subsection{EMPLOYMENT NOTICES AND APPLICATIONS:}

The published advertisement through print media and interaction with hard copies were the main source of getting information and submitting application for employment both in private and public jobs. Private job advertisements were published both in print and electronic medias and in their particular websites. However, it is recently added development in the public service delivery provided by the public agencies. From Advertisements to publishing the final appointments are being widely practiced in government sectors. It brings numerous benefits for job seekers. There are many privately maintained websites where employment notices are often posted (http://www.bangladesh.gov.bd/). Bangladesh government links thorough web portal and provides necessary services required for employment. This also connects the overseas employment and maintains regular updating in the websites as there are more than 8 million Bangladeshi expatriates are currently living and helping the country economy.

\subsection{OVERSEAS COMMUNICATION:}

Under the A2I program, Union Information Service Centre (UISC) has been established in every union (lower level of local government) with computer lab to provide all necessary services to the citizens. About 8 million Bangladesh expatriates are currently living away from their family members. People at the rural areas can easily utilize the internet service at UISC to talk to their 
family members through skype, google talk and send emails (http://www.bangladesh.gov.bd/). Earlier they used to spend money for phone which was costly. Not only the education people rural illiterate people can use skype or other internet services with the help of union staff.

\subsection{LAW AND ORDER INFORMATION:}

The recent innovations of Bangladesh government regarding the services provided to the citizen are related to law and order information. Now citizen can get any useful information in the webisites and can lodge complaint in the interactive websites.

\subsection{LOCAL GOVERNMENT ACTIVITIES:}

The government initiatives regarding the local government and rural development issues, such allocation of fund for roads construction, disaster management and mitigation, funds for education, health, social welfare, special activities are available in the government websites with full financial statement and allocation (http://www.bangladesh.gov.bd/). Local government representatives are now more transparent and accountable to citizens.

\subsection{AGRICULTURE:}

Agriculture related information has been made available for all with the help of policy makers, technology innovators, academics or researchers, farmers, traders, media personnel as well as entrepreneurs $[10,11]$. Hence the skeleton of e-Agriculture is purposely developed for the following various target groups:

\section{Decision support}

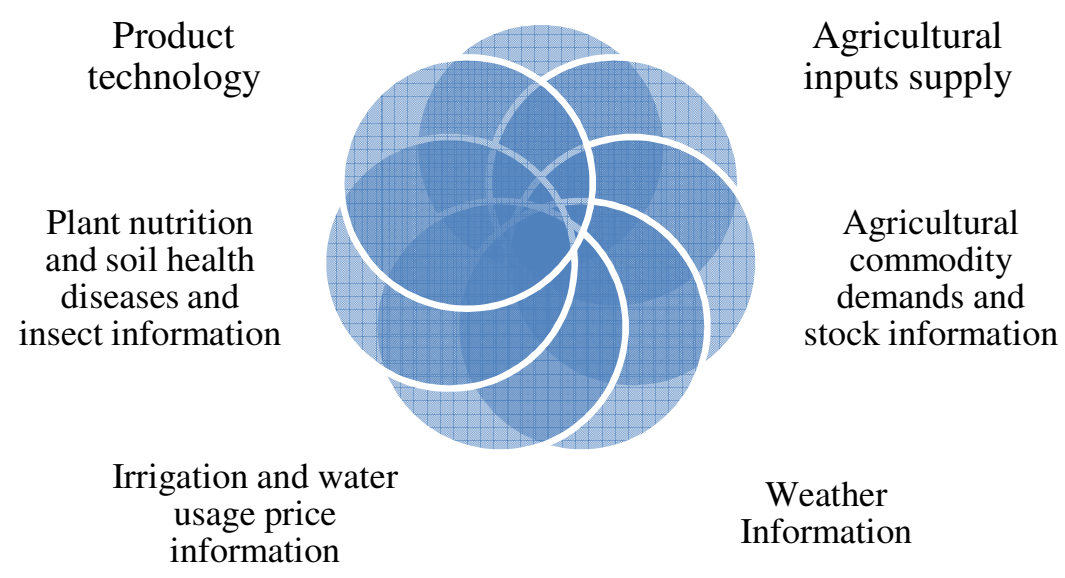

Figure-1: Services of e-Agriculture

Source: developed by authors

Services are provided under the following categories: 


\section{Service delivery on Web or from Database:}

Web interface or website will provide periodically updated information and data in static pages. More specific and customized information or data could be obtained by entering query in the front end or dynamic pages, which will connect user to the database server. Initially only Internet users will be able to reach that service. Gradually it will be made available to mobile phone users via SMS using Location Based Service (LBS) of the Mobile Switching Center (MSC).

\section{Telecenter or Call Center:}

It could be maintained by a folk of smart operators and Agricultural experts. They will be responsible for providing answer to the queries of a farmer or a stakeholder using Web or databases on the server. In case, when information is not available on the database, the operator can redirect the phone to an expert who is attending there for answering variety of questions to provide real time information service. A setup of a Call Center and Toll Free telephone service can make people more interested to get information from Telecenter.

\section{Info Center or local Telecenter:}

It could be established in a village or at local market places where people usually get together being equipped with Internet Service, telephony and multimedia projector. People are attracted there for Audio-visual presentations of documentaries, drama, movie and technological knowhow. Together with entertainment service, the Infotain operator/facilitator will help them to provide information for free by browsing web, making queries to the database or making phone calls to the Telecenter (http://community.telecentre.org/profiles/blogs/eagriculture-in-bangladesha).

\section{THE PROCESS AND MECHANISM FOLLOWED TO PROVIDE BETTER SERVICES TO THE CITIZEN OF BANGLADESH}

The radical shift from the paper based service procedures to e-government is the prime issue for providing services at the doorsteps of the citizen of Bangladesh. Since District Administration popularly known as DC office (Deputy Commissioner) is the main public service providing center for the government with a historical time of more than two hundred years. There are as many as 37 types of necessary services are provided from this point regarding control and supervision of revenue, maintenance of public order and security, license and certificates, land acquisitions, census, relief and rehabilitation, social welfare, pension matters, education and public examinations, public complaints and enquiries. DC office is the coordinator for local government systems actively maintained by its subordinate offices at Upazilla level. It is a mammoth task of provide several services to the huge population of the particular districts, the country as whole, services were used to provide labor intensive time consuming paper services. The vital reasons related to inflexibility, corruption, delays above all demand from the citizen forced to change the service delivery system for which the District e-Service Centre has been established with an ICT facilitated one-stop service point in order for improving the accessibility and transparency of public service delivery system at the district. It was designed to achieve the following objectives related to public service delivery:

$\checkmark$ Ensure service delivery at the lowest possible time, and if possible, promptly

$\checkmark$ Uphold citizens' Rights to Information through extensive information flow

$\checkmark$ Save time and labor when processing services

$\checkmark$ Increase the number of clients served through digitization of all information and services

$\checkmark$ Reduce corruption and increase accountability of government officials by ensuring better flow of information and more transparent processes. 


\subsection{OPERATIONAL PROCEDURE}

It is the beauty of district e-service center that citizen can submit their application through district web portal from their home to receive public services mentioned above by using the facility of the centre. The process followed to provide services to the citizen can be presented as diagram below:

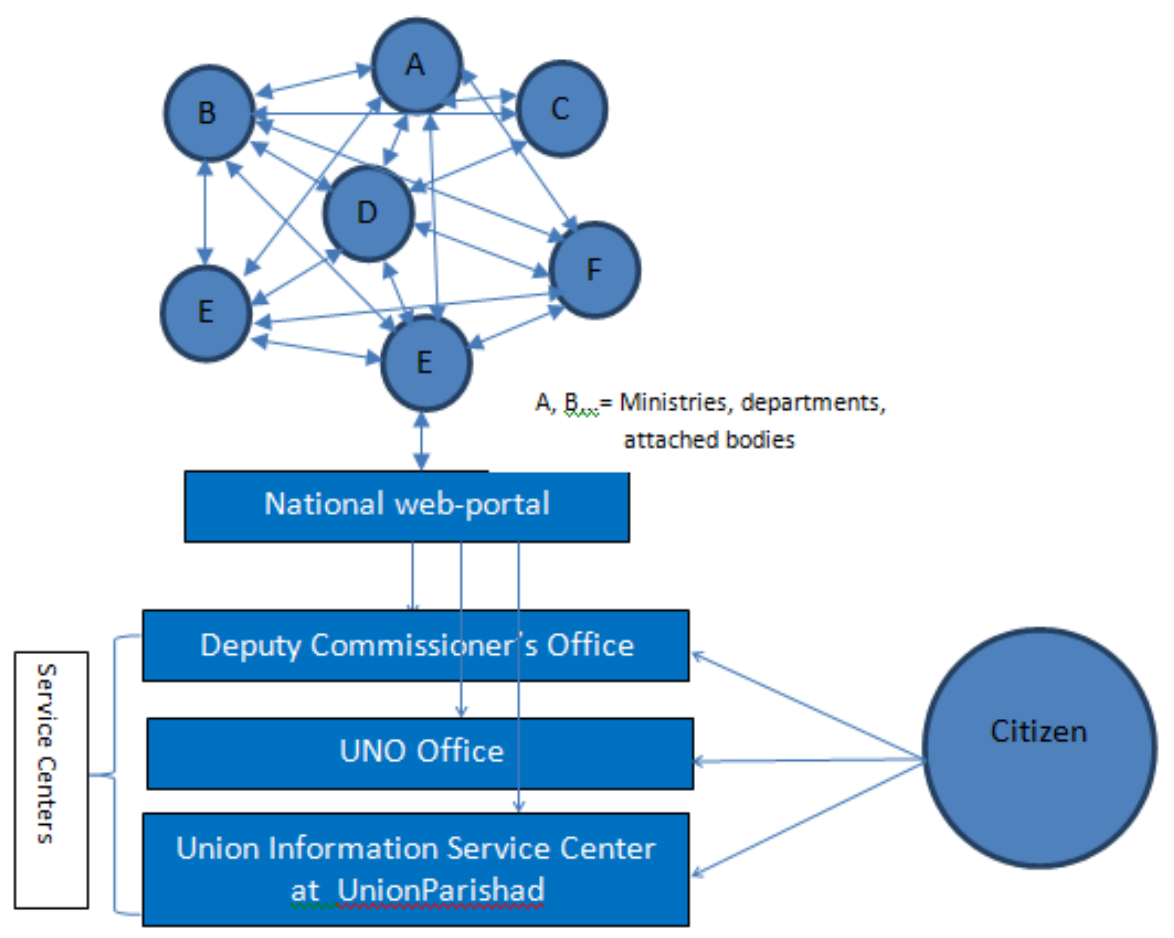

The detailed operational procedures combines submission, processing, tracking and copies of records:

\subsection{SUBMISSION OF APPLICATIONS REGARDING SERVICES}

Citizens can submit applications and official letters in three ways: over the counter, by post and online at the District Portal (http://www.bangladesh.gov.bd/). Service applications and applications details are recorded on e-Centre computers. Details are sent, online to relevant officials, and applicants provided with a receipt and tracking number, to follow their applications through the process. Applications can also be submitted from the office of UpazillaNirbahi Officers (Upazilla Executive Officers), avoiding the travel to District Head Quarters. Citizens who provide their information online instantly receive a receipt with their 'Receive Number' both online, as well as to their mobile phones by SMS. This service was primarily started by the Deputy Commissioner of Jessore district of Bangladesh.

\subsection{PROCESSING OF APPLICATIONS}


Government officers log into a password-protected system and access a dashboard where they view their day's task lists, as well as those of their colleagues. Case files sent to government officers include relevant case information, including case history up to that point (http://www.bangladesh.gov.bd/). An officer cannot forward applications to other officers without making the required preliminary decision. Once processing of an application is complete, all notes and decisions regarding the case are stored in hard copy in the main file.

\subsection{TRACKING TO KNOW THE UPDATES OF SERVICES AND APPLICATION}

Citizens in districts can call the dedicated e-Centre numbers and track the status of their applications by giving their "Receive Numbers". They can also track the statues through SMS and internet. Citizens can use the online District Portal to track the status of applications.

\subsection{HARD AND SOFT COPIES OF RECORDS}

All applications for certified copies of records are entered into the e-Centre's computers. In case of any change in the delivery date, applicants are notified through SMS. Citizen then have 30 days to send the required fee to the DC office from any Bank. Once this fee is received, applicants receive the delivery date (http://www.bangladesh.gov.bd/). Citizens can also receive certified copies of land records by post by sending a self-addressed envelope along with the fee.

As the primary intervention was with the district office, services related to DC offices were available to provide, later that extended to provide various services. Government then set Union Information Service Center which has become the main point to submit application for all kinds of services. Services are provided with a minimum cost.

\section{CITIZEN'S RESPONSE AND RECOMMENDATIONS PROVIDED FOR FURTHER SOLUTION}

The several advantages achieved through utilization of public resources established across country at the door steps of citizen have encouraged citizen to enjoy the public services more effectively. It has created the platform to get services within minimum time and facing less problems. Citizen across the country has made critical comments on the services provided through web portal and e-centers. People who suffered from the delay, corruptions, misbehaviour of government officials; have made comments regarding the recent developments of the government regarding services provided through e-service centre:

It is very good job..we don't need to go office $100 \mathrm{~km}$ from our home to collect one single land related documents. Now we can apply in our union, and can get copy. I don't need to spend to travel, not need to spend more money..no hazardous.. etc. .. when we went to land office, many people come to us, ask to give extra money, problems and problems...

(Fokrul, a farmer, owner of piece of land, Gopalpur, Tangail)

Source [12]

It gave great help to the students who need to go outside of their rural area to study higher education. All higher educational institutions are mainly situated either in the capital or big cities in the country [13]. In order to apply to any university of college, students used to go that particular institute and apply. As applications are available in the website and government has 
changed the admission procedures, the primary cost is not needed which would be very troublesome. One student remarks:

Interesting it is fantastic progress and good service that government provided. We don't need to the particular university far from here... I went when I got chance..it save me much. I am from poor family. I cannot spend for travelling. For this initiative, I also got my certificate from the shop in the rural area. I just printed it off. That's all.

(Moin, University student, Dhaka) (Source [14])

The establishment of UISC at every union provides very good opportunities for the family members of Bangladesh expatiate. A woman who husband works in Singapore response to a journalist saying:

.. at the very beginning it was difficult to talk to my husband. I used to spend 200 taka per call. Now only 10-20 talk, I can talk to him and can see him. I feel happy. Though privacy is not there. But it is very good. Government did very good thing for us..

(Kallyani, a rural woman) (Source [12])

There is lots of information related to agriculture provided through online and mobile. Farmers can easily get through mobile dialling a particular number. Using mobile by farmers was an unthinkable issue where they can easily utilize this technology for the development of policy initiatives of the government. One agriculture researcher has pointed out benefits of the service: Government and private mobile operators are working hand in hand. Since everybody has mobile, government providing necessary information for the welfare of the farmers and they are also asking for their crops what to do when they need to put such thing, and asked even what are remedies in case of any problem.

Helal, Researcher, Mymensingh

(Soruce:http://community.telecentre.org/profiles/blogs/eagriculture-in-bangladesh-a)

Besides benefits, people place several recommendations for the better services as well. Research findings that the following suggestions are required for the citizens [10, 15].

a) Setting Village Information Centre: All necessary information should be provided through village Info Centers as majority of people live in rural area the situation in the villages is worse than that in the city. Village information centres can be a solution to provide necessary information.

b) Mobile based complaint center: It is revolutionary change in Bangladesh that about 80 percent people are now currently using mobile for their day to communication. Establishing online mobile phone based complaint center can be used as a strong tool to provide service to the mass people and develop further.

c) Awareness Programs: Arranging more TV programs to make citizen aware of every necessary issue regarding the socio economic development that covers development programs like agricultural program, health care, education, gender issue etc. and let people know which type of services they can get and where these services are available.

d) Weather Forecast through Mobile: As Bangladesh has agriculture based economy, farmers and villagers should know weather forecast through mobile phones. It can be used to 
broadcast weather forecast in times of national emergency and natural disasters so that they take measures to minimize the consequences.

e) Circulating labor laws and information regarding overseas working: About 8 million

f) Bangladeshi expatriates are currently working across world whose most of them are semi-skilled and unskilled labour. They should know all necessary information about the rules and regulations. Promoting labour policies and laws in mass communication channels because most of the day labourers are not aware about their rights due to illiteracy. Radio and television can be used to inform and aware them about their rights.

g) Extension of service area: Submission of utility bills through SMS should be extended as payment of utility bill is a hassle and time consuming for general people. It wastes important working hours. Broader ICT delivery channels, like SMS, web etc can be used to pay the utility bills.

h) Establishing IT infrastructure: Internet which could decrease the educational expenses because internet can be used to deliver education to every corner of the country. Distance learning should be strengthened as our infrastructure for formal education is still lacking in resources. Bangladesh still lacks of electrify and government could not meet the demand. In that case, it might be provided urgently to get the benefit from the IT resources.

i) Disability-friendly IT resources: Making disability-friendly software which is still underestimated in our country. Government should take some steps so that other organization can be influenced from this. In this regard, Government can develop read out software to teach the blind people.

\section{CONCLUSION}

Utilizing the e-government infrastructure Bangladesh government has reached to the people and provided services at their doorsteps by establishing the national web portal through which citizen can access their useful services. It was viewed that empowerment of people, transparency and accountability, human resource development, poverty alleviation and economic growth would be ensured as people would receive better, faster public services and have access to all kinds of public information if Digital Bangladesh is established. Regarding the public services related to health service, education service, bill payment of necessary service, income tax payment, trade licence, land records, agricultural issues, law and order service are now easily enjoyed from the house through internet. However, the faster speed of customer demand in getting all services cannot be addressed with the limited IT infrastructure, unskilled manpower, limited electricity supply which should be solved as quickly as possible by emphasizing and initiating new programs. Government should think the intended and unintended consequences of materializing some initiatives and take necessary steps before intensifying the problem and making people unhappy with the services that have already been provided [16]. Public offices in Bangladesh should also consider the various degree of resistance to change at organizational, group and individual levels and initiate organizational development at three levels to reduce the resistance and to proliferate forces for change for innovations which will ultimate lead to sustainability and effectiveness [17].

\section{ACKNOWLEDGMENTS}


This paper was prepared for presentation in the 2014 World Conference for Public Administration of the Korean Association of Public Administration held in 25-27 June, 2014 in Daegu, Korea. I express heartiest thanks to Professor PonlapatBuracom, Ph.D., Program Director of PhD Program in Development Administration (International), Graduate School of Public Administration, National Institute of Development Administration (NIDA) and Professor SuchitraPunyaratabandhu, Ph.D., Director, 30 Years of Public Administration, Thailand for providing financial support to my friend, Mr. Md. Rasel Mahmud Khan who attended the conference to present paper on my behalf. I also acknowledge the contribution of the Korean Association of Public Administration (KAPA).

\section{REFERENCE}

[1] Denhardt, Robert B., and Janet VinzantDenhardt. "The new public service: Serving rather than steering." Public administration review 60, no. 6 (2000): 549-559.

[2] Layne, Karen, and Jungwoo Lee. "Developing fully functional E-government: A four stage model." Government Information Quarterly 18, no. 2 (2001): 122-136..

[3] Presthus, Robert V. "Weberian v. Welfare Bureaucracy in Traditional society." Administrative Science Quarterly (1961): 1-24.

[4] Fang, Zhiyuan. "E-government in digital era: concept, practice, and development." International journal of the Computer, the Internet and management 10, no. 2 (2002): 1-22.

[5] Bailey, Kenneth D. "Methods of Social Research". $4^{\text {th }}$ edn. New York: The Free Press. 1994.

[6] GoB (Government of Bangladesh) (GoB). "The Right to Information Act, 2009." Dhaka: Government Publications

[7] Bhuiyan, Shahjahan H. "Modernizing Bangladesh Public Administration through e-governance: Benefits and Challenges." Government Information Quarterly 28, no. 1 (2011): 54-65.

[8] Rajon, SA Ahsan, and Sk Ali Zaman. "Implementation of e-governance: Only Way to Build a Corruption-free Bangladesh." In Computer and Information Technology, 2008.ICCIT 2008. 11th International Conference on, pp. 430-435. IEEE, 2008.

[9] Ndou, Valentine. "E-government for Developing Countries: Opportunities and Challenges." The Electronic Journal of Information Systems in Developing Countries 18 (2004).

[10] Islam, M. Sirajul, and ÅkeGrönlund. "Agriculture Market Information e-service in Bangladesh: A Stakeholder-oriented Case Analysis" Electronic GovernmentLecture Notes in Computer Science, Volume 4656, 2007, pp 167-178

[11] Ntaliani, Maria, ConstantinaCostopoulou, SotiriosKaretsos, EfthimiosTambouris, and KonstantinosTarabanis. "Agricultural e-government services: An implementation framework and case study." Computers and Electronics in Agriculture 70, no. 2 (2010): 337-347.

[12] Ali, Shahed: "Success of Digital Bangladesh" (in Bangla). The Daily BhorerKagoj(Bangla News paper), 2010, January, 29.

[13] Karim, Mohammad Rezaul. "Public Education Spending and Income Inequality in Bangladesh”.International Journal of Social Science and Humanity, Vol. 5, No. 1 (2015):75-79

[14] Khan, Mozzamel. "The issue of e-governance in Bangladesh". The Daily Jugantor( Bangla Newspaper), 2011, April 21.

[15] ...... "Factors Influencing the Adoption of Mobile Phones among the Farmers in Bangladesh: Theories and Practices”, International Journal on Advances in ICT for Emerging Regions, 2011 $04(01): 4-14$

[16] Margetts, Helen, and Christopher Hood, eds. Paradoxes of Modernization: Unintended Consequences of Public Policy Reform. Oxford University Press, 2010.

[17] Jones, Gareth R. "Organizational Theory, Design and Change: Text and Case". 4th ed. New Jersey: Prentice Hall, Ch 10 